\title{
Stanowisko grupy ekspertów dotyczące miejsca iwabradyny w optymalizacji terapii u chorych z przewlekłą niewydolnością serca
}

\author{
Expert group consensus regarding the place of ivabradine \\ in therapy optimization in patients with chronic heart failure
}

\author{
Marcin Barylski ${ }^{1}$, Małgorzata Lelonek ${ }^{2}$, Artur Mamcarz $^{3}$, Agnieszka Mastalerz-Migas ${ }^{4}$ \\ ${ }^{1}$ Klinika Chorób Wewnętrznych i Rehabilitacji Kardiologicznej Uniwersytetu Medycznego w Łodzi \\ ${ }^{2}$ Zakład Kardiologii Nieinwazyjnej Uniwersytetu Medycznego w Łodzi
}

${ }^{3}$ III Klinika Chorób Wewnętrznych i Kardiologii II Wydziału Lekarskiego Warszawskiego Uniwersytetu Medycznego

${ }^{4}$ Katedra i Zakład Medycyny Rodzinnej Uniwersytetu Medycznego we Wrocławiu

\section{Streszczenie}

Przyspieszona częstość rytmu serca stanowi czynnik ryzyka śmiertelności ogólnej oraz sercowo-naczyniowej w różnych populacjach pacjentów. Stosowanie klasycznych leków zwalniających rytm serca, takich jak beta-adrenolityki czy antagoniści wapnia z grupy niedihydropirydynowych (werapamil i diltiazem), jest często ograniczone z powodu ich działań niepożądanych. Iwabradyna jest unikatowym, nowoczesnym lekiem, którego mechanizm działania polega na blokowaniu prądu I, w węźle zatokowo-przedsionkowym. Przekłada się to na zmniejszenie częstości rytmu serca - parametru związanego z niekorzystnym rokowaniem u pacjentów z niewydolnością serca (HF). Niniejszy dokument stanowi opinię grupy ekspertów będącą podsumowaniem aktualnej wiedzy dotyczącej iwabradyny i jej zastosowania w populacji chorych z HF. Słowa kluczowe: optymalizacja terapii, niewydolność serca, iwabradyna

Folia Cardiologica 2018; 13, 6: 534-544

\section{Wprowadzenie}

Niewydolność serca (HF, heart failure) jest obecnie jednym z najpoważniejszych problemów zdrowotnych Polaków. Szacuje się, że w Polsce na HF może chorować nawet około miliona osób, a liczba nowych przypadków szacowana jest na 220 tys. w ciągu roku [1]. Na świecie HF stanowi istotny problem zdrowia publicznego - dotyczy on aż 23 mln osób. W Stanach Zjednoczonych częstość występowania HF szacuje się na 5,7 mln [2]. Wśród krajów reprezentowanych w Europejskim
Towarzystwie Kardiologicznym (ESC, European Society of Cardiology) liczba pacjentów z HF wynosi około $15 \mathrm{mln}$ [3].

Biorąc pod uwage, że do HF prowadzą takie schorzenia, jak choroba wieńcowa, nadciśnienie tętnicze, cukrzyca czy otyłość, kolejnym czynnikiem jest również zwiększająca się populacja osób starszych, z całą pewnością można stwierdzić, że pacjentów z HF będzie przybywać. Ryzyko wystąpienia HF w populacji europejskiej dla osoby w wieku 55 lat wynosi 33\% dla mężczyzn i 29\% dla kobiet, po 85 . roku życia zrównuje się ono dla obu płci i wynosi 17,4\% [4, 5].

Adres do korespondencji: dr n. med. Marcin Barylski FESC, Klinika Chorób Wewnętrznych i Rehabilitacji Kardiologicznej, Uniwersytet Medyczny w Łodzi, Uniwersytecki Szpital Kliniczny im. Wojskowej Akademii Medycznej, Centralny Szpital Weteranów, Plac Hallera 1, 90-647 Łódź, tel. 4263930 80, faks 4263930 80, e-mail: mbarylski3@wp.pl 
Mimo znacznego postępu medycyny rokowanie w HF jest nadal poważne. W ciągu 5 lat z powodu tej choroby umiera 60\% mężczyzn i 40\% kobiet. Śmiertelność całej populacji chorych z HF, niezależnie od etiologii, wynosi około $10 \%$ rocznie. Liczba pacjentów z tym schorzeniem jest 2,5-krotnie większa niż liczba chorujących na wszystkie nowotwory łącznie. Codziennie 117 Polaków umiera z powodu HF, rocznie liczba zgonów sięga 43 tys. [6]. Aż połowa pacjentów umiera w ciągu 5 lat od rozpoznania choroby [4]. Są to istotnie gorsze dane statystyczne niż w przypadku raka sutka, jajnika czy prostaty. W związku z tym należy dołożyć wszelkich starań, aby poprawić rokowanie, stosując kompleksowe, zgodne z wytycznymi leczenie.

\section{Hospitalizacja w niewydolności serca - aspekty ekonomiczne}

Roczne koszty leczenia chorych z HF w Polsce zwiększyły się do 1,7 mld zł i stanowią już 3,2\% budżetu Narodowego Funduszu Zdrowia (NFZ) [1]. Według danych Instytutu Zarządzania w Ochronie Zdrowia w 2009 roku wszystkie rozpoznania w ramach $\mathrm{HF}$ stanowiły $7,17 \%$ hospitalizacji ogółem wśród kobiet powyżej 65. roku życia i 6,77\% w grupie mężczyzn powyżej 65. roku życia [7]. W 2012 roku NFZ sfinansował świadczenia dla pacjentów leczonych z powodu HF w wysokości ponad $672 \mathrm{mln}$ zł [7]. Najwięcej wydano na świadczenia szpitalne - $635 \mathrm{mln}$ zł (94\%), następnie rehabilitację leczniczą - $26 \mathrm{mln}$ zł (4\%) oraz ambulatoryjną opiekę specjalistyczną - $10 \mathrm{mln}$ zł (2\%). Udział tych kosztów w całości świadczeń wyniósł 2,2\% w przypadku lecznictwa szpitalnego, 1,3\% w przypadku rehabilitacji oraz $0,2 \%$ w przypadku ambulatoryjnej opieki specjalistycznej [7].

Niewydolność serca jest najczęstszą przyczyną hospitalizacji wśród osób po 65. roku życia. W 2012 roku NFZ rozliczył leczenie tej choroby w grupie 288 tys. pacjentów ogółem, przy czym 158 tys. stanowiły osoby powyżej 69. roku życia [7]. Tryb nagły przyjęcia do szpitala dotyczył prawie 83\% ogólnej liczby przyjęć. W 2012 roku w Polsce 187 tys. chorych przyjęto do szpitala z powodu HF, a co 4 pacjent był ponownie hospitalizowany w czasie krótszym niż 30 dni od wypisania.

Polska znalazła się na pierwszym miejscu wśród 30 krajów Organizacji Współpracy Gospodarczej i Rozwoju (OECD, Organisation for Economic Co-operation and Development) pod względem liczby hospitalizacji z powodu HF, wyprzedziła pod tym względem Stany Zjednoczone, Niemcy i Austrię [8]. Liczba hospitalizacji w naszym kraju 2-krotnie przekracza średnią dla OECD. W 2012 roku koszty związane z hospitalizacją 187,5 tys. pacjentów wynosiły $635 \mathrm{mln}$ zł, co daje średnio około 3400 zł/rok/pacjenta. Średni okres hospitalizacji pacjentów z HF (grupa E53; HF u osób > 69. rż. lub z powikłaniami i chorobami współistniejącymi) w 2012 roku w Polsce wynosiła 6 dni (mediana)
[7]. Przewiduje się, że przy wzroście liczby chorych z HF o $25 \%$ w ciągu najbliższych 20 lat związane z tym koszty leczenia wzrosną 2-krotnie.

\section{Optymalna częstość rytmu serca - cel terapii kardiologicznej}

Przyspieszony rytm serca (HR, heart rate) jest jednym z podstawowych i wczesnych objawów HF. Koreluje on z zaawansowaniem choroby niezależnie od jej etiologii, jest uznanym objawem o wartości prognostycznej. Samo przyspieszenie pracy serca, jeśli jest znaczne i trwa odpowiednio długo, może pogarszać kurczliwość i stać się wyłączną przyczyną HF. Stan taki określa się kardiomiopatią tachyarytmiczną, która według obowiązującej klasyfikacji należy do grupy pierwotnych kardiomiopatii nabytych [9]. Tachykardia jest także uznanym czynnikiem zaburzającym napełnianie komór serca i nasilającym objawy dysfunkcji rozkurczowej lub niewydolności serca z zachowaną frakcją wyrzutową (HFpEF, heart failure with preserved ejection fraction). Niedokrwienie prowokowane przez niedostatecznie kontrolowaną HR może prowadzić do hibernacji miokardium i odwracalnego pogorszenia funkcji skurczowej komór.

Zgodnie z wynikami licznych badań zarówno śmiertelność z przyczyn sercowo-naczyniowych, jak i śmiertelność całkowita u chorych z HF jest wprost proporcjonalna do HR.

Kluczowe dane definiujące HR co najmniej 70/min jako powiązaną z gorszym rokowaniem uzyskano $\mathrm{w}$ badaniu BEAUTIFUL (morBidity, mortality EvAIUaTion of the IF inhibitor ivabradine in patients with coronary disease and left-ventricULar dysfunction), które dotyczyło standardowo leczonej populacji z niedokrwienną dysfunkcją lewej komory serca. Co niezwykle ważne - zwolnienie HR pozwala na obniżenie śmiertelności w tej grupie pacjentów. Stało się to podstawą zastosowania leków, dzięki którym HR jest stosunkowo łatwo modyfikowalnym parametrem wpływającym na rokowanie w HF.

Wyniki licznych badań klinicznych potwierdziły wysoką skuteczność terapeutyczną zwalniania HR w HF - początkowo uzyskiwanej wyłącznie dzięki lekom beta-adrenolitycznym. Zmiana HR nie jest jedynym elementem działania beta-adrenolityków - poza działaniem chronotropowo ujemnym efekt blokowania aktywacji układu adrenergicznego powoduje między innymi redukcję groźnych zaburzeń $\mathrm{HR}$, zmniejsza niedokrwienie i pozawałowe uszkodzenie mięśnia sercowego oraz przeciwdziała remodelingowi lewej komory. Osiągnięta podczas leczenia HR jest ponadto dobrym wskaźnikiem jego skuteczności - metaanaliza McAlistera i wsp. [10] oparta na danych z 23 badań dotyczących skurczowej HF wykazała, że z korzyściami klinicznymi koreluje stopień zwolnienia HR, a nie dawka beta-adrenolityku. Przy redukcji śmiertelności w całej grupie o średnio 24\% wykazano, że zwolnienie HR o 5/min 
(ale nie osiągnięcie określonej dawki leku) zmniejsza śmiertelność o 18\% ( $p=0,006)$ [10].

Te silne dowody na zmniejszanie śmiertelności u chorych z HF w II-IV klasie według New York Heart Association (NYHA) i obniżenie ryzyka innych kluczowych powikłań powodują, że beta-adrenolityki od lat należą do pierwszej linii leczenia w skurczowej HF i są rekomendowane łącznie z inhibitorami konwertazy angiotensyny (ACE, angiotensin-converting enzyme) u wszystkich pacjentów z EF poniżej 40\% w celu redukcji częstości hospitalizacji z powodu HF i ryzyka przedwczesnego zgonu. Co istotne, zalecenia nie uznają efektu klasy i dotyczą leków przebadanych w prospektywnych próbach klinicznych: metoprololu o przedłużonym uwalnianiu, bisoprololu, karwedilolu i - mimo braku pełnych dowodów na zmniejszenie śmiertelności ogólnej - nebiwololu.

Powszechne stosowanie beta-adrenolityków wiąże się jednak z ryzykiem działań niepożądanych, nierzadkich u chorych w HF. Stanowi to główną przyczynę niedostatecznego dawkowania lub braku włączania tej grupy leków mimo oczywistych korzyści. Hipotonia, nasilenie chromania przestankowego lub objawów bronchospastycznych należą do najczęstszych przyczyn. W pewnym odsetku przypadków stosowanie beta-adrenolityków nawet w prawidłowo dobranej dawce wyraża się pogorszeniem parametrów układu oddechowego. Choć w mięśniach gładkich drzewa oskrzelowego dominują receptory beta ${ }_{2}$, ocenia sie, że odsetek receptorów beta ${ }_{1}$ sięga $20 \%$ i dlatego także stosowanie leków beta ${ }_{1}$-selektywnych może wywołać zaostrzenia przebiegu astmy oraz przewlekłej obturacyjnej choroby płuc. Prowadzi to do potwierdzonej luki terapeutycznej - zaledwie $22 \%$ polskich pacjentów z HF przyjmuje optymalną dawkę beta-adrenolityku, a 23\% nie otrzymuje go w ogóle [11]. Również dane z rejestru DATA HELP wskazują, że mediana HR polskich pacjentów z HF przekracza 70/min [12, 13].

Niewątpliwie najbardziej newralgicznym okresem po wypisaniu pacjenta ze szpitala jest pierwszych kilka tygodni, kiedy ryzyko zgonu i ponownej hospitalizacji z powodu HF jest największe [14]. Według badań w obu przypadkach ryzyko było najwyższe w ciągu miesiąca od wypisu do domu, a następnie stopniowo spadało, w szczególności w odniesieniu do zgonów spowodowanych postępem HF i nagłym zgonem sercowym. Omawiane ryzyko zgonu jest tym wyższe, im dłużej pacjent był hospitalizowany (co zapewne wiąże się z bardziej zaawansowaną HF) i im więcej hospitalizacji doświadczył w przeszłości. Niestety znaczna część chorych wypisywanych ze szpitala po zaostrzeniu HF ma wciąż podwyższoną częstość HR [15].

Spośród grupy ocenianej w rejestrze OPTIMIZE-HF (Organized Program to Initiate Lifesaving Treatment in Hospitalized Patients with Heart Failure) jedynie 73\% osób wypisywanych ze szpitala było leczonych beta-adrenolitykiem. $\mathrm{U}$ chorych, u których nie zastosowano beta-adrenolityku, mediana HR wynosiła 80/min (rozstęp ćwiartkowy [IQR, interquartile range] 70-89/min) w porównaniu z HR 78/min (IQR 69-88/min) u pacjentów przyjmujących mniej niż 25\% dawki docelowej, HR 75/min (IQR 66-85/min) u pacjentów stosujących 25-49\% dawki docelowej, HR 74/min (IQR 66-82/min) przy 55-99\% dawki docelowej oraz HR 72/min (IQR 65-80/min) u pacjentów, u których udało się osiągnąć 100\% docelowej dawki beta-adrenolityku. Dane z przywołanego rejestru pokazują, że $71 \%$ pacjentów jest wypisywanych ze szpitala z HR serca co najmniej 70/min, w tym $63 \%$ stanowią osoby wypisane z co najmniej $50 \%$ dawki docelowej beta-adrenolityku. Niestety, co potwierdzono również w rejestrze OPTIMIZE-HF, nie dochodzi do dalszej optymalizacji dawki leków beta-adrenolitycznych w warunkach ambulatoryjnych. Zgodnie z danymi z cytowanego rejestru po 60. i 90. dniach od wypisania aż 70-75\% pacjentów (zależnie od rodzaju przyjmowanego beta-adrenolityku) przyjmowało identyczną dawkę leku z zaordynowaną przy wypisaniu ze szpitala, a u 9-13\% chorych dawkę zmniejszono w stosunku do wypisu. Jedynie w około 15\% przypadków podjęto próbę zwiększenia i dalszej optymalizacji leczenia beta-adrenolitycznego. Po 60. i 90. dniach od wypisania tylko, odpowiednio, 17,5\% oraz 7,9\% pacjentów leczonych było docelową dawką beta-adrenolityku [16]. Dlatego zwłaszcza osoby, które były hospitalizowane w powodu HF, powinny w momencie wypisania ze szpitala otrzymać optymalne leczenie modyfikujące dalszy przebieg choroby, w tym także mieć odpowiednio zredukowaną częstość HR. Każda ponowna hospitalizacja może świadczyć o nieskuteczności dotychczasowego schematu/strategii leczenia i powtarzanie go bez zmian (obejmujących również adekwatną modyfikację częstości HR) nie gwarantuje uniknięcia ponownej hospitalizacji.

Należy w tym miejscu wspomnieć również o rejestrze QUALIFY - międzynarodowym, prospektywnym, obserwacyjnym badaniu dotyczącym 7092 pacjentów z HF, którzy w ciągu 1-15 miesięcy poprzedzających włączenie do badania byli hospitalizowani z powodu HF. W badaniu analizowano, ilu chorych po wypisaniu ze szpitala przestrzega wytycznych dotyczących stosowania inhibitorów ACE, beta-adrenolityków, sartanów, antagonistów aldosteronu i iwabradyny. Na podstawie wyników stwierdzono że $67 \%$ pacjentów przestrzega zaleceń w stopniu dobrym, $25 \%$ w umiarkowanym, a $8 \%$ chorych w złym. Z danych polskich pacjentów rejestru QUALIFY wynika, że dla inhibitorów ACE jedynie $27 \%$ chorych ambulatoryjnych osiągało dawkę docelową, dla sartanów - 4\%, beta-adrenolityków - 17,7\%, a w przypadku antagonistów aldosteronu - 66\% [17]. W porównaniu z danymi światowymi polscy pacjenci rejestru QUALIFY częściej są leczeni rekomendowanymi w wytycznych standardowymi grupami leków (inhibitory ACE/sartany, beta-adrenolityki i antagoniści aldosteronu) z wyjątkiem iwabradyny (33\% wyniki baseline na świecie v. 13,9\% w Polsce) [17]. Na świecie już co 3. pacjent jest 
leczony iwabradyną, natomiast w Polsce stosuje się ją u co 7. ambulatoryjnego pacjenta z HF, choć aż u $25 \%$ polskiej populacji rejestru QUALIFY rejestrowano rytm zatokowy z częstością większą lub równą 75/min [17]. Ponadto jedynie 39,2\% chorych z rytmem zatokowym osiągało spoczynkową częstość HR poniżej 70/min.

Dane te pokazują, że w Polsce nie wykorzystuje się możliwości optymalizacji terapii pacjentów z HF w kontekście możliwości zwolnienia częstości HR. Udowadniają także, że wykorzystywanie w codziennej praktyce wszystkich rekomendowanych terapii, w tym iwabradyny, jest jedyną droga do dalszej poprawy rokowania w tej trudnej grupie pacjentów. Warto również podkreślić, że dawkowanie iwabradyny nie jest skomplikowane, wymaga analizy rytmu w elektrokardiogramie i kontroli częstości rytmu w celu ustalenia dawkowania, co powinno pozostawać w gestii lekarza podstawowej opieki medycznej czy kardiologa ambulatoryjnego.

\section{Iwabradyna - charakterystyka leku}

\section{Działanie}

Iwabradyna należy do nowej klasy leków wybiórczo zwalniających częstość HR. Mechanizm jej działania polega na selektywnym i specyficznym hamowaniu prądu jonowego $I_{f}$ w komórkach węzła zatokowego [18]. Wchodzą one w skład grupy komórek rozrusznikowych, mających zdolność do spontanicznego wytwarzania potencjałów czynnościowych. W mechanizmie automatyzmu komórek rozrusznikowych biorą udział cztery typy kanałów błonowych i płynące przez nie prądy jonowe, $w$ tym prąd rozrusznikowy $I_{f}$ płynący przez kanał $\mathrm{f}$. Kanał $\mathrm{f}$ należy do rodziny kanałów jonowych HCN (hyperpolarization-activated cyclic nucleotide-gated channel), których obecność stwierdzono jedynie w sercu, w niektórych okolicach mózgu i w siatkówce oka, a to, że wystąpienie prądu $\mathrm{I}_{\mathrm{f}}$ jest inicjowane przez hiperpolaryzację, czyni go na tyle nietypowym, że w momencie jego wykrycia w 1979 roku nazwano go funny ('zabawny, dziwny'). Do tego momentu uważano, że kanały jonowe w komórkach sercowych są aktywowane jedynie w wyniku depolaryzacji błony komórkowej [19].

Kanały f podlegają także bezpośredniej aktywacji przez cząsteczki cyklicznego adenozyno-3'-5'-monofosforanu (cAMP, cyclic adenosine monophosphate), które znajdują się wewnątrz komórek. Stymulacja receptorów beta-adrenergicznych prowadzi do aktywacji cyklazy adenylanowej, która powoduje zwiększenie stężenia cAMP, co prowadzi do aktywacji prądu $I_{f}$, skrócenia czasu rozkurczowej depolaryzacji, skrócenia fazy rozkurczu oraz do przyspieszenia częstości HR [4, 20, 21].

W wyniku blokowania kanału f następuje zatem zwolnienie spoczynkowej depolaryzacji węzła zatokowego w okresie rozkurczu, a w efekcie - zwolnienie częstości HR. Iwabradyna działa wyłącznie na węzeł zatokowy i nie wpływa na czas przewodnictwa w przedsionkach, w węźle przedsionkowo-komorowym lub w komorach serca ani na kurczliwość mięśnia sercowego (poza działaniem wynikającym ze zwolnienia częstości HR) lub na repolaryzację komory. Uważa się, że ma nieznaczny i klinicznie nieistotny wpływ na ciśnienie krwi i opór naczyniowy [22, 23]. Chociaż w badaniach przedklinicznych nie obserwowano istotnego wpływu iwabradyny na czas trwania skorygowanego odstępu QT ani PR [24], to u ludzi, w niektórych przypadkach, zwolnienie czynności serca związane ze stosowaniem iwabradyny może nasilić wydłużenie odstępu QT. Dlatego też należy zachować szczególną ostrożność lub unikać podawania iwabradyny u pacjentów z zespołem długiego odstępu QT lub przyjmujących leki wydłużające odstęp QT [23].

Selektywne działanie iwabradyny na węzeł zatokowy jest unikatową cechą wśród leków stosowanych w celu zwolnienia częstości HR. Pozostałe substancje, w tym beta-adrenolityki, niedihydropirydynowe pochodne antagonistów wapnia (werapamil i diltiazem), amiodaron czy digoksyna, wywołują jednocześnie efekt hipotensyjny, zmniejszają kurczliwość mięśnia sercowego i mogą działać proarytmicznie, co w przypadku pacjentów z HF stanowi istotne ograniczenie ich stosowania [13].

W zalecanych dawkach iwabradyna zwalnia częstość HR w spoczynku, a także w trakcie wysiłku o około 10/min. Jej siła blokowania $\mathrm{I}_{\mathrm{f}}$ zwiększa się wraz z częstością rytmu serca, dlatego im większa częstość HR przed włączeniem leczenia, tym większy efekt terapeutyczny [18]. Lek ten zwiększa objętość wyrzutową serca, co przy jednoczesnym zwolnieniu jego czynności powoduje, że pojemność minutowa serca pozostaje niezmieniona. Jest to cecha odróżniająca iwabradynę od beta-adrenolityków, które przez zmniejszenie kurczliwości serca prowadzą do zmniejszenia jego pojemności wyrzutowej oraz minutowej $[25,26]$. Chociaż kanały fobecne są także w niższych piętrach mięśnia sercowego, w warunkach fizjologicznych pozostają nieaktywne, dlatego iwabradyna zmniejsza częstość HR tylko u pacjentów z rytmem zatokowym [25].

Warto podkreślić, że iwabradyna wykazuje zdolność wiązania z kanałem $\mathrm{ftylko}$ wtedy, kiedy jest on otwarty. Dlatego też skuteczniej łączy się ze swoim miejscem wiązania wówczas, gdy szybko zachodzą po sobie cykle zamykania i otwierania kanału f, czyli - jak już wspomniano - wtedy, gdy częstość HR jest większa. Z kolei dzięki tej właściwości lek działa tym słabiej, im jest ona wolniejsza, w efekcie zmniejsza się ryzyko ciężkiej bradykardii [27].

\section{Farmakokinetyka i farmakodynamika}

Po podaniu doustnym iwabradyna szybko i prawie całkowicie wchłania się z przewodu pokarmowego. Czas do osiągnięcia maksymalnego stężenia we krwi $\left(\mathrm{T}_{\max }\right)$ po podaniu na czczo wynosi godzinę. Dostępność biologiczna, ze względu na efekt pierwszego przejścia w jelitach i wątrobie, 
wynosi około 40\%. Pokarm opóźnia wchłanianie leku o blisko godzinę i zwiększa ekspozycję na niego w osoczu o 20-30\%. Iwabradyna w około $70 \%$ wiąże się z białkami osocza. Jest ona w znacznym odsetku metabolizowana w wątrobie i w jelitach w procesie oksydacji wyłącznie przez izoenzym CYP3A4 cytochromu P450. Głównym czynnym metabolitem jest pochodna N-demetylowa. Ekspozycja na te substancję odpowiada około $40 \%$ ekspozycji na substancję macierzystą. Metabolizm tego czynnego metabolitu również zachodzi z udziałem izoenzymu CYP3A4. Iwabradyna charakteryzuje się małym powinowactwem do CYP3A4, nie wykazuje klinicznie istotnego działania pobudzającego lub hamującego na ten izoenzym, dlatego też uważa się za mało prawdopodobne, że wpływa na metabolizm innych jego substratów lub stężenia tych substancji w osoczu. Natomiast substancje o silnym działaniu hamującym lub pobudzającym CYP3A4 mogą mieć znaczny wpływ na stężenia iwabradyny w osoczu. Biologiczny okres półtrwania $\left(T_{1 / 2}\right)$ w fazie eliminacji wynosi $2 \mathrm{~h}$, a efektywny $t_{1 / 2}-11 \mathrm{~h}$. Metabolity są wydalane w podobnym stopniu z kałem i moczem; około 4\% dawki wydala się z moczem w postaci niezmienionej. Podeszły wiek oraz zaburzenia funkcji nerek nie wpływają na farmakokinetykę leku. U pacjentów z umiarkowanymi zaburzeniami czynności wątroby stężenia iwabradyny i jej głównego metabolitu są o około $20 \%$ większe niż u pacjentów z prawidłową czynnością wątroby. Lek jest przeciwwskazany w ciąży i w okresie karmienia piersią, a kobiety w wieku rozrodczym muszą stosować skuteczne metody zapobiegania ciąży w trakcie terapii [23]. Możliwe jest też dożylne podanie iwabradyny, obecnie jednak nie istnieje parenteralna postać tego leku [28].

\section{Wskazania do stosowania}

Od 2005 roku iwabradyna znajduje zastosowanie w leczeniu objawowej przewlekłej stabilnej dławicy piersiowej u osób z chorobą niedokrwienną serca i z prawidłowym rytmem zatokowym. Zaleca się ją u pacjentów z nietolerancją lub z przeciwwskazaniem do stosowania beta-adrenolityków.

Od 2009 roku, po opublikowaniu wyników badania ASSOCIATE (evaluation of the Antianginal efficacy and Safety of the aSsociation of the If Current Inhibitor ivAbradine with a beTa-blockEr), dopuszczono ją do stosowania w skojarzeniu z beta-adrenolitykami u osób, u których nie uzyskano odpowiedniej kontroli za pomocą optymalnej dawki beta-adrenolityku i u których częstość HR jest większa lub równa 70/min.

W lutym 2012 roku, po ogłoszeniu wyników badania SHIFT (Systolic Heart failure treatment with the IF inhibitor ivabradine Trial), pojawiło się kolejne wskazanie - przewlekła HF w II-IV klasie według klasyfikacji NYHA, z zaburzeniami czynności skurczowej, u pacjentów z rytmem zatokowym, u których częstość HR wynosi co najmniej 75/min, w skojarzeniu z leczeniem standardowym, w tym z beta-adrenolitykiem, lub gdy leczenie beta-adrenolitykiem jest przeciwwskazane albo nie jest tolerowane [23].

\section{Działania niepożądane}

Iwabradyna jest uważana za lek relatywnie bezpieczny, generalnie wywołuje działania niepożądane u niewielkiego odsetka pacjentów, jeśli się pojawią, to zwykle są niegroźne. Najczęściej mamy do czynienia z zaburzeniami widzenia (mogą dotyczyć ok. 14,5\% leczonych pacjentów), opisywanymi jako przemijające wrażenia widzenia silnego światła w części pola widzenia (zazwyczaj wywołane przez nagłe zmiany natężenia światła; na ogół występują w pierwszych 2 miesiącach terapii). Nieco rzadziej (1-10\% pacjentów) występują: niewyraźne widzenie, bradykardia (szczególnie w pierwszych 2-3 miesiącach, w tym u 0,5\% pacjentów ciężka bradykardia < 40/min), blok przedsionkowo-komorowy I stopnia, dodatkowe skurcze komorowe, bóle głowy (głównie w pierwszym miesiącu leczenia), zawroty głowy (prawdopodobnie związane z bradykardią), niekontrolowane ciśnienie tętnicze i migotanie przedsionków. Dzięki zdolności wiązania się iwabradyny z kanałem f tylko wtedy, kiedy jest on otwarty - czyli w efekcie słabszego działania przy wolniejszej częstości HR, o czym już wspominano - częstość HR nie może ulec zwolnieniu bardziej niż o 18-20\% wartości wyjściowej [27, 29]. Dodatkową ochroną jest to, że podczas stosowania iwabradyny w wyższych dawkach, na przykład 20 mg 2 razy/dobę, zmniejszenie częstości akcji serca nie jest proporcjonalne do stężenia iwabradyny w osoczu i obserwuje się tendencję do wystąpienia plateau [23].

\section{Interakcje}

Iwabradyna jest metabolizowana wyłącznie przez izoenzym CYP3A4 cytochromu P450 i jest bardzo słabym inhibitorem tego izoenzymu, nie wpływa więc na metabolizm innych substratów CYP3A4 i ich stężenia w osoczu. Należy jednak pamiętać, że inhibitory CYP3A4 zwiększają stężenia iwabradyny w osoczu, natomiast substancje o działaniu pobudzającym ten izoenzym zmniejszają jej stężenie. Zwiększone stężenia iwabradyny w osoczu mogą powodować ryzyko nasilonej bradykardii. Dlatego przeciwwskazane jest jednoczesne stosowanie iwabradyny z silnymi inhibitorami CYP3A4, takimi jak azolowe pochodne przeciwgrzybicze (flukonazol, itrakonazol, ketokonazol), antybiotyki makrolidowe (erytromycyna, josamycyna, klarytromycyna, telitromycyna), inhibitory proteazy ludzkiego wirusa nabytego niedoboru odporności (HIV, human immunodeficiency virus) (nelfinawir, rytonawir) i nefazodon. Silne inhibitory CYP3A4 - ketokonazol (200 mg/d.) oraz josamycyna (1 g $2 \times /$ d.) - zwiększają 7-8-krotnie średnie narażenie na iwabradynę w osoczu. Nie zaleca się jednoczesnego stosowania iwabradyny z lekami wydłużającymi odstęp QT, na przykład chinidyną, dizopiramidem, bepridilem, sotalolem, ibutilidem, amiodaronem, pimozidem, ziprasidonem, sertindolem, meflochiną, halofantryną, pentamidyną, 


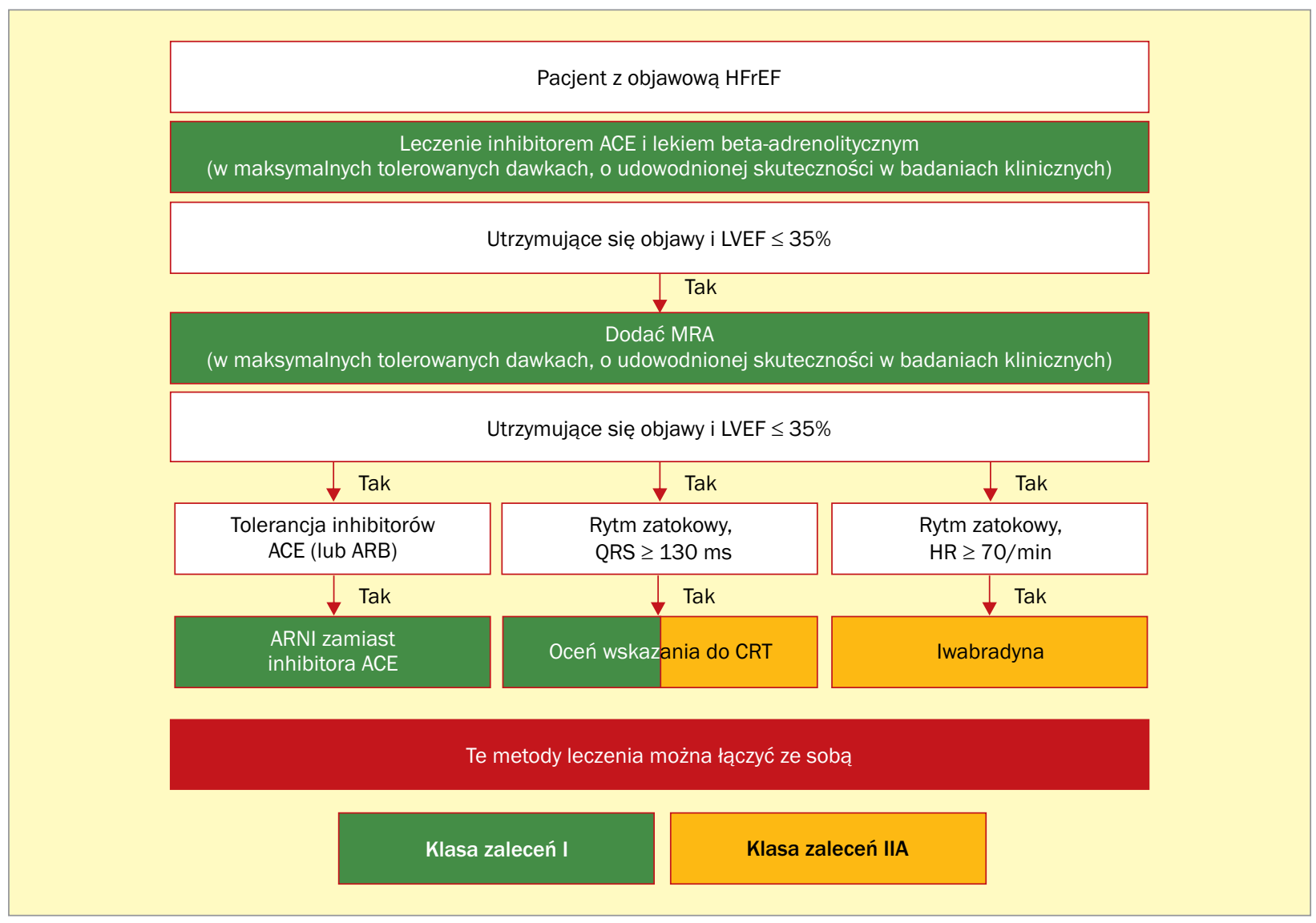

Rycina 1. Wytyczne Europejskiego Towarzystwa Kardiologicznego (ESC, European Society of Cardiology) dotyczące diagnostyki i leczenia ostrej i przewlekłej niewydolności serca w 2016 roku - fragment algorytmu terapii pacjentów z niewydolnością serca z obniżoną frakcją wyrzutową lewej komory (HFrEF, heart failure with reduced ejection fraction) (zmodyfikowano na podstawie [32]); ACE (angiotensin-converting enzyme) - inhibitor konwertazy angiotensyny; ARB (angiotensin receptor blocker) - antagonista receptora dla angiotensyny II/sartan; ARNI (angiotensin receptor neprilisin inhibitor) - antagonista receptora dla angiotensyny i inhibitor neprilizyny; CRT (cardiac resynchronisation therapy) - elektryczna terapia resynchronizująca; HR (heart rate) - częstość akcji serca; LVEF (left ventricular ejection fraction) - frakcja wyrzutowa lewej komory serca; MRA (mineralocorticoid receptor antagonist) - antagonista receptora mineralokortykoidowego/ /antagonista aldosteronu; QRS - szerokość zespołu QRS w zapisie elektrokardiograficznym

cisapridem, erytromycyną dożylnie. Jeśli takie skojarzenie jest konieczne, należy ściśle monitorować czynność serca. Podawanie iwabradyny w skojarzeniu z diltiazemem lub werapamilem powodowało zwiększenie jej stężenia w osoczu oraz dodatkowe zmniejszenie częstości HR o 5/min, dlatego jednoczesne stosowanie tych leków z iwabradyna jest przeciwwskazane. Spożywanie soku grejpfrutowego w trakcie leczenia zwiększa 2-krotnie siłę działania iwabradyny, dlatego należy ograniczyć jego spożycie podczas leczenia. Leki pobudzające CYP3A4, w tym rifampicyna, barbiturany, fenytoina oraz preparaty dziurawca zwyczajnego, mogą zmniejszać stężenie iwabradyny w osoczu i tym samym osłabiać jej działanie [23].

\section{Miejsce i dawkowanie iwabradyny}

w przewlekłej HF

Od 2012 roku jest do dyspozycji nowy lek o unikatowym działaniu, dzięki któremu - jak wykazano w wynikach badania
SHIFT - możliwe jest aż 26-procentowe zmniejszenie ryzyka hospitalizacji pacjentów z HF oraz 26-procentowe zmniejszenie ryzyka zgonu z powodu HF jako pompy [30, 31]. Leczenie iwabradyną należy rozpocząć u osób ze stabilną HF, u których mimo zastosowania standardowego leczenia (tj. inhibitora ACE lub antagonisty receptora angiotensyny II w przypadku nietolerancji tego pierwszego, beta-adrenolityku oraz antagonisty receptora mineralokortykoidowego) utrzymują się objawy w II-IV klasie według NYHA, frakcja wyrzutowa lewej komory (LVEF, left ventricular ejection fraction) nie przekracza 35\%, pacjent ma rytm zatokowy, a jego częstość wynosi co najmniej 70/min (ryc. 1) [32]. Podawanie iwabradyny w wymienionej grupie pacjentów można rozważyć także u osób nietolerujących beta-adrenolityków [32].

Patrząc na przedstawiony na rycinie 1 algorytm, warto sugerować się następującymi praktycznymi wskazówkami: - pierwszeństwo stosowania CRT powinno dotyczyć pacjentów z blokiem lewej odnogi pęczka Hisa 


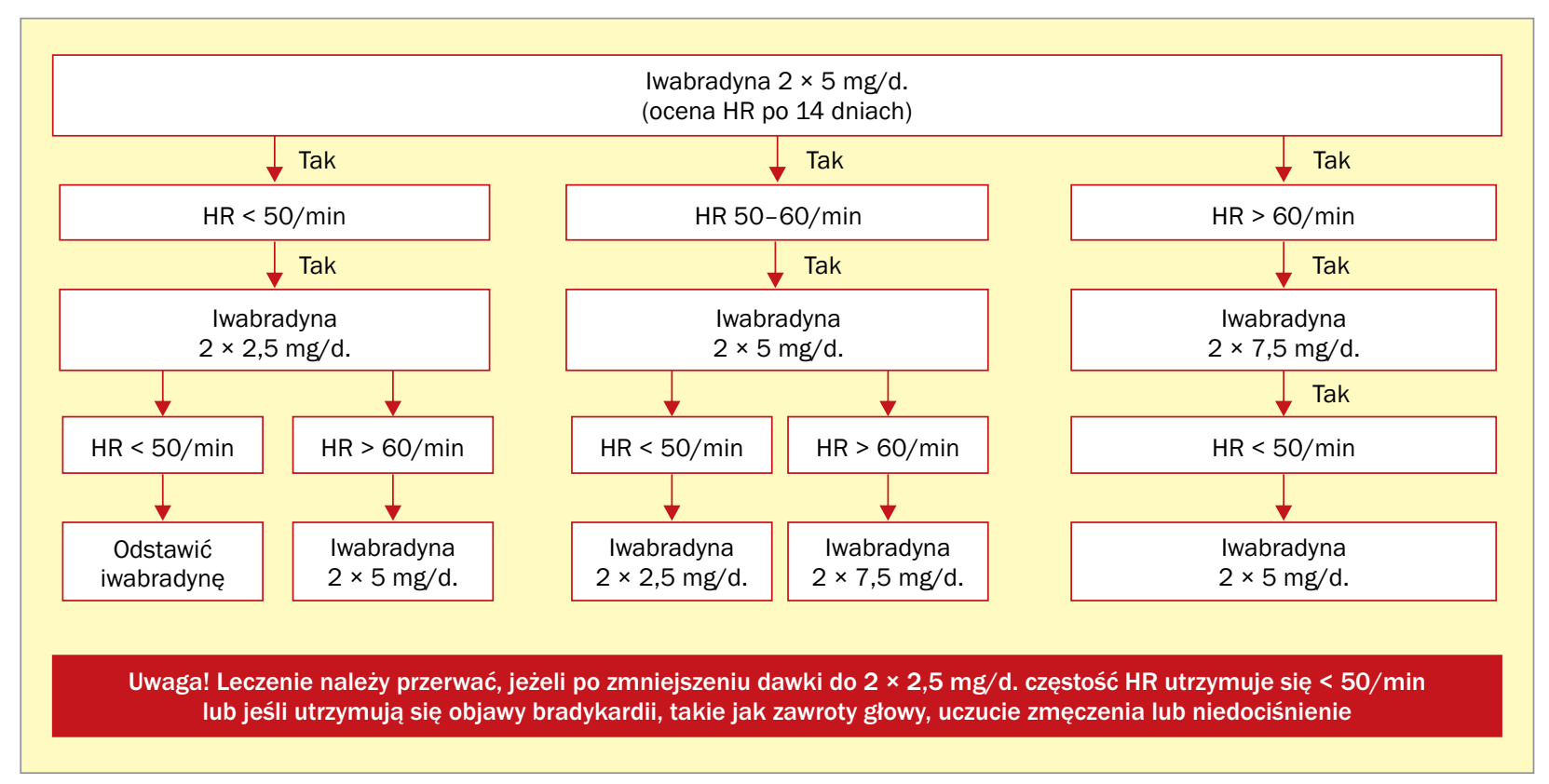

Rycina 2. Schemat dawkowania iwabradyny u pacjentów z niewydolnością serca (na podstawie [25]); HR (heart rate) - rytm serca

i szerokością zespołów QRS powyżej 150 ms (ta grupa najbardziej korzysta z tej formy terapii);

- pierwszeństwo stosowania iwabradyny powinno dotyczyć pacjentów z rytmem zatokowym i częstością akcji serca co najmniej 75/min mimo stosowania optymalnej dawki beta-adrenolityku lub przy jego nietolerancji albo przeciwwskazaniu do jego stosowania;

- pierwszeństwo wdrażania antagonisty receptora dla angiotensyny i inhibitora neprilizyny zamiast dotychczasowych inhibitorów ACE powinno dotyczyć pacjentów mających nadal objawy, LVEF serca nie większą niż $35 \%$ oraz podwyższone stężenia peptydów natriuretycznych (peptydu natriuretycznego typu B [BNP, B-type natriuretic peptide] $\geq 150 \mathrm{pg} / \mathrm{ml} \mathrm{lub} \mathrm{N-końcowego} \mathrm{frag-}$ mentu propeptydu natriuretycznego typu B [NT-proBNP, $N$-terminal pro-BNP] $\geq 600 \mathrm{pg} / \mathrm{ml}$ ).

Warto jednak pamiętać, że wszystkie trzy sposoby postępowania można ze sobą dowolnie łączyć.

W tym miejscu należy zwrócić uwagę na różnicę między wytycznymi a zarejestrowanym wskazaniem do stosowania dla iwabradyny. Otóż w rejestracji Europejskiej Agencji Leków (EMA, European Medicines Agency), a tym samym w charakterystyce produktu leczniczego, wskazaniem do włączenia iwabradyny jest częstość HR co najmniej 75/ /min, natomiast według wytycznych ESC ta granica częstości HR jest niższa i wynosi co najmniej 70/min. W wynikach subanalizy badania SHIFT wykazano istotną korzyść z dołączenia iwabradyny w podgrupie chorych ze spoczynkowym tętnem co najmniej 75/min, stąd pojawienie się tej rozbieżności. Należy jednak oczekiwać ujednolicenia tych wskazań [23, 32].
Leczenie iwabradyną (ryc. 2) zaczyna się zwykle od dawki $5 \mathrm{mg} 2$ razy/dobę, po 2 tygodniach dawkę można zwiększyć do 7,5 mg 2 razy/dobę, jeśli częstość HR w spoczynku wynosi stale powyżej 60/min, lub zmniejszyć do 2,5 mg 2 razy/dobę (1/2 tabl. po 5 mg 2 ×/d.) w przypadku wystąpienia subiektywnych objawów bradykardii lub długotrwałego zmniejszenia częstości HR poniżej 50/ /min. Gdy częstość HR wynosi 50-60/min, należy utrzymać dawkę 5 mg 2 razy/dobę. Jeśli podczas leczenia częstość HR w spoczynku trwale się zmniejszy do poniżej 50/min lub jeśli pojawią się objawy związane z bradykardią, to u pacjentów otrzymujących dawkę $7,5 \mathrm{mg} 2 \mathrm{razy} /$ dobę lub $5 \mathrm{mg} 2$ razy/dobę należy ją zmniejszyć. Jeśli częstość HR w spoczynku zwiększy się trwale do powyżej 60/min, u pacjentów otrzymujących 2,5 mg 2 razy/dobę lub $5 \mathrm{mg}$ 2 razy/dobę dawkę można zwiększyć. Leczenie należy przerwać, jeśli częstość HR pozostaje poniżej 50/min lub utrzymują się objawy bradykardii. U osób w podeszłym wieku powinno się rozważyć zastosowanie dawki początkowej 2,5 mg 2 razy/dobę. Nie ma konieczności modyfikacji dawkowania u osób z klirensem kreatyniny powyżej $15 \mathrm{ml} / \mathrm{min}$. U osób z klirensem kreatyniny poniżej $15 \mathrm{ml} / \mathrm{min}$ należy zachować szczególną ostrożność, gdyż brakuje danych dotyczących bezpieczeństwa stosowania iwabradyny w tej grupie pacjentów. Nie ma konieczności modyfikacji dawkowania u osób z lekkimi zaburzeniami czynności wątroby, przy zaburzeniach umiarkowanych zaś należy zachować ostrożność [23].

Szczególne zainteresowanie budzi możliwość stosowania iwabradyny u chorych, u których powinno się unikać podawania beta-adrenolityków (w przypadku bloku 
przewodnictwa przedsionkowo-komorowego I stopnia, choroby naczyń obwodowych, astmy oskrzelowej lub ciężkiej przewlekłej obturacyjnej choroby płuc). W przeciwieństwie do beta-adrenolityków iwabradynę można również stosować w naczynioskurczowych postaciach dławicy, ponieważ nie zaburza równowagi naczynioruchowej naczyń wieńcowych. Iwabradyna wydaje się również ważną opcją terapeutyczną u osób przyjmujących agonistów receptorów beta-adrenergicznych z następową tachykardią, u mężczyzn w średnim wieku, u których szczególnie dotkliwe są potencjalne zaburzenia funkcji seksualnych po zastosowaniu beta-blokady, oraz u starszych pacjentów z wydłużeniem odstępu PR.

\section{Badania nad iwabradyną}

\section{Badanie BEAUTIFUL}

W latach 2008-2009 opublikowano wyniki badania BEAUTIFUL. Miało ono ocenić wpływ iwabradyny dodanej do standardowego leczenia choroby niedokrwiennej serca na śmiertelność i chorobowość z przyczyn sercowo-naczyniowych. Było to pierwsze tak duże badanie z iwabradyną, obejmujące ponad 10 tys. pacjentów z udokumentowaną stabilną chorobą wieńcową, dysfunkcją skurczową lewej komory (z LVEF < 40\% i wymiarem końcoworozkurczowym lewej komory w osi krótkiej > $56 \mathrm{~mm}$ ) i rytmem zatokowym w spoczynku powyżej 60/min. Pierwotny złożony punkt końcowy obejmował zgon z przyczyn sercowo-naczyniowych i leczenie szpitalne z powodu ostrego zawału serca oraz nowej lub zaostrzonej HF. Drugorzędowe punkty końcowe obejmowały dodatkowo: śmiertelność ogólną, śmiertelność z powodu choroby niedokrwiennej serca i HF oraz hospitalizacje z powodu choroby niedokrwiennej serca, HF lub konieczności rewaskularyzacji. W badaniu nie wykazano różnicy w częstości występowania pierwotnego złożonego punktu końcowego w grupie przyjmującej iwabradynę w porównaniu z grupą otrzymującą placebo. Natomiast u pacjentów z częstością HR co najmniej 70/min iwabradyna istotnie zmniejszała: ryzyko zawału serca - o 36\% $(p<0,001)$, oraz ryzyko rewaskularyzacji wieńcowej o 30\% (p=0,016) [33].

W analizie pacjentów leczonych standardowo (grupa kontrolna) stwierdzono, że HR co najmniej 70/min znamiennie zwiększa ryzyko: zgonu sercowo-naczyniowego o 34\% ( $p=0,0041)$, hospitalizacji z powodu HF o 53\% $(p<0,001)$, hospitalizacji z powodu zawału serca o $46 \%$ $(p=0,0066)$ i rewaskularyzacji wieńcowej o 38\% $(p=0,037)$. Przyspieszenie spoczynkowej HR o każde 5/min zwiększało ryzyko zgonu sercowo-naczyniowego o 8\% $(p=0,0005)$, hospitalizacji z powodu HF o 16\% ( $p<0,001)$, hospitalizacji z powodu zawału serca o $7 \%(p=0,052)$ i rewaskularyzacji wieńcowej o 8\% ( $p=0,034)$. Na podstawie wyników tych można stwierdzić, że ryzyko zgonu oraz wystąpienia punktu końcowego związanego z HF wzrasta w sposób ciągły przy HR powyżej 70/min, natomiast taki związek w przypadku wieńcowych punktów końcowych jest mniej wyraźny [34].

\section{Badanie ASSOCIATE}

W badaniu ASSOCIATE wykazano, że iwabradyna w połączeniu $z$ atenololem wykazuje dodatkowe działanie przeciwdławicowe i poprawę parametrów testu wysiłkowego na bieżni, nie wpływając jednocześnie na tolerancję i bezpieczeństwo leczenia. W badaniu wzięło udział 889 chorych z przewlekłą stabilną chorobą wieńcową, otrzymujących atenolol w dawce $50 \mathrm{mg} /$ dobę, randomizowanych do grupy leczonej iwabradyną w dawce $5 \mathrm{mg}$, a następnie $7,5 \mathrm{mg} 2$ razy/dobę lub placebo. Uczestników próby 3-krotnie poddano testom wysiłkowym: wyjściowo oraz po 2 i 4 miesiącach terapii. Po 4 miesiącach w grupie leczonej iwabradyną odnotowano między innymi istotne wydłużenie całkowitego czasu trwania wysiłku (o 24,3 \pm 65,3 s w grupie leczonej iwabradyną v. 7,7 $\pm 63,8$ s w grupie przyjmującej placebo; $p<0,001$ ), czasu do obniżenia odcinka ST o $1 \mathrm{~mm}$ (o 45,7 $\pm 93 \mathrm{~s}$ w grupie leczonej iwabradyną v. 15,4 $\pm 86,6 \mathrm{~s}$ w grupie przyjmującej placebo; $p<0,001)$ oraz czasu do wystąpienia dolegliwości dławicowych (odpowiednio: 49,1 \pm 83,3 s oraz $22,7 \pm 79,1 \mathrm{~s} ; \mathrm{p}<0,001$ ) [35]. Rezultaty tego badania wraz z wynikami badania BEAUTIFUL umożliwiły zalecenie jednoczesnego stosowania beta-adrenolityków z iwabradyną.

\section{Badanie SHIFT}

Wiadomo, że wysoka częstość HR wiąże się z gorszym rokowaniem w wielu chorobach sercowo-naczyniowych, między innymi w HF, i nie obniża się u wielu tych pacjentów mimo stosowania beta-adrenolityków. Autorzy badania SHIFT zadali sobie pytanie, czy dodanie iwabradyny do standardowego leczenia HF może wpłynąć na redukcję liczby hospitalizacji tych pacjentów [31].

Odpowiedź od 2010 roku znają już wszyscy kardiolodzy. Po 23 miesiącach obserwacji stwierdzono istotną (o 18\%) redukcję częstości występowania głównego punktu końcowego, na który składały się zgon z przyczyn sercowo-naczyniowych i hospitalizacja z powodu dekompensacji HF. Korzyści obserwowano prawie we wszystkich prospektywnie zdefiniowanych podgrupach pacjentów. Jak wynika z analizy poszczególnych składowych głównego punktu końcowego, iwabradyna zmniejsza o 9\% ryzyko zgonu sercowo-naczyniowego (różnica nieistotna statystycznie) oraz aż o $26 \%$ ryzyko hospitalizacji z powodu dekompensacji HF $(p<0,0001)$ [31].

Ciekawa jest obserwacja płynąca z subanalizy echokardiograficznej badania SHIFT, w której okazało się, że iwabradyna wpływa na remodeling i funkcję mięśnia lewej komory. W grupie pacjentów leczonych iwabradyną w porównaniu z pacjentami otrzymującymi placebo obserwowano: 
zmniejszenie indeksu objętości końcowoskurczowej lewej komory (LVESVI, left ventricular end-systolic volume index) o $7 \pm 16,3$ w porównaniu z 0,9 $\pm 17,1 \mathrm{ml} / \mathrm{m}^{2}$ ( $p<0,001$ ), zmniejszenie indeksu objętości końcoworozkurczowej lewej komory (LVEDVI, left ventricular end-diastolic volume index) o 7,9 $\pm 18,9 \mathrm{w}$ porównaniu z 1,8 $\pm 19 \mathrm{ml} / \mathrm{m}^{2}$ $(p=0,002)$ oraz zwiększenie LVEF o $2,4 \pm 7,7 \%$ w porównaniu z $0,1 \pm 8 \%(p<0,001)$ [36].

Na początku niniejszego stanowiska podkreślono znaczenie starzenia się populacji oraz prognoz dotyczących rosnącej liczby pacjentów z HF. Biorąc pod uwagę, że hospitalizacja jest jednym z najsilniejszych niezależnych czynników złego rokowania w HF i pogarsza jakość życia, a z ekonomicznego punktu widzenia stanowi najważniejszą część kosztów związanych z leczeniem HF, redukcja ryzyka hospitalizacji o ponad $25 \% \mathrm{w}$ wyniku stosowania iwabradyny w badaniu SHIFT, a tym samym w praktyce klinicznej, nabiera szczególnej wagi.

\section{Badanie SIGNIFY}

Badanie, którego wyniki ogłoszono we wrześniu 2014 roku, miało odpowiedzieć na pytanie, czy redukcja częstości HR za pomocą iwabradyny przełoży się na zmniejszoną zachorowalność i śmiertelność pacjentów ze stabilną chorobą wieńcową, z zachowaną funkcją lewej komory i bez klinicznych cech HF. W badaniu wzięło udział 19102 pacjentów z ponad 1139 ośrodków. Włączono do niego chorych w wieku co najmniej 55 lat, ze stabilną chorobą wieńcową, z LVEF powyżej 40\%, z rytmem zatokowym o wyjściowej częstości co najmniej 70/min, obciążonych co najmniej jednym czynnikiem ryzyka choroby wieńcowej. Chorych losowo przydzielono do grupy leczonej iwabradyną (9550 osób) w dawce dostosowywanej tak, by osiągnąć spoczynkowy HR 55-60/min, lecz nie większej niż 20 mg/ /dobę (dawka 2 × 10 mg nie jest zarejestrowana do stosowania) oraz do grupy przyjmującej placebo [37].

Włączenie iwabradyny spowodowało zmniejszenie spoczynkowej częstości HR o 10/min (9,7/min; 95-proc. przedział ufności [Cl, confidence interval]). Jednak w ciągu prawie 28 miesięcy obserwacji nie odnotowano różnic w częstości występowania złożonego punktu końcowego zdefiniowanego jako wystąpienie zgonu z przyczyn sercowo-naczyniowych lub niezakończonego zgonem zawału serca między obiema grupami (6,8\% [iwabradyna] v. 6,4\% [placebo]; $p=0,20$; współczynnik ryzyka = 1,08).

Wyniki badania SIGNIFY (Study assessInG the morbidity-mortality beNefits of the IF inhibitor ivabradine in patients with $C A D$ ) nie zmienią roli iwabradyny w terapii HF, ponieważ dotyczyły innej populacji pacjentów. Na pewno jednak skłaniają do zachowania ostrożności i zdrowego rozsądku w dążeniu do uzyskania optymalnej częstości HR, której dolna granica wciąż pozostaje nieznana, a jak wiadomo z doświadczenia - najlepszy jest zawsze złoty środek.

\section{Badanie ETHIC-AHF}

Niekorzystnym czynnikiem rokowniczym przy wypisywaniu chorego z HF jest wysoka częstość HR. U części chorych już na etapie szpitalnym może być w takiej sytuacji przydatne dołączenie iwabradyny do leczenia beta-adrenolitykiem. Tego typu strategia wydaje się korzystna dla pacjentów z rytmem zatokowym i HR co najmniej 70/min, hospitalizowanych po raz kolejny z powodu zaostrzenia HF. Ponowna hospitalizacja wskazuje, że dotychczasowa strategia leczenia okazała się nieskuteczna i nie daje możliwości uniknięcia ponownego pobytu w szpitalu bez modyfikacji terapii.

Celem badania ETHIC-AHF (Early Therapy with Ivabradine in patients with Congestive Acute Heart Failure) była ocena wpływu wczesnego, jednoczesnego podawania iwabradyny $(2 \times 5-7,5 \mathrm{mg} / \mathrm{d}$.) z beta-adrenolitykiem (bisoprololem lub karwedilolem) - grupa badana, w porównaniu z monoterapią beta-adrenolitykiem w optymalnej dawce (bisoprolol $10 \mathrm{mg} /$ d., karwedilol $50 \mathrm{mg} / \mathrm{d}$.) lub w maksymalnej dawce tolerowanej - grupa kontrolna, u pacjentów z HF z obniżoną EF. Autorzy przeanalizowali roczne wyniki obserwacji, porównując te dwie strategie leczenia u chorych z rytmem zatokowym i częstością HR powyżej 70/min [38].

Do badania zakwalifikowano 71 chorych (33 w grupie badanej i 38 w grupie kontrolnej). Po 28 dniach częstość HR była niższa w grupie badanej $(64,3 \pm 7,5$ v. 70,3 $\pm 9,3$ / /min; $p=0,01)$, i różnica ta utrzymała się również po roku terapii $(61,8 \pm 5,5$ v. $68,4 \pm 9,3 / \mathrm{min} ; p=0,01)$. Dawki beta-adrenolityków były podobne w obu grupach [38].

Po rocznej obserwacji LVEF była znacznie większa w grupie badanej $(48,2 \pm 17 \%$ v. $41,8 \pm 10 \%$; $p=0,002)$. Ryzyko zgonu sercowo-naczyniowego było o $26 \%$ niższe w grupie leczonej iwabradyną, jednak w porównaniu z grupą kontrolną nie osiągnięto istotności statystycznej [38].

Mimo że badanie ETHIC-AHF było niewielką próbą kliniczną, to udowodniono w nim, że intensyfikacja leczenia ma szczególne znaczenie w okresie największej wrażliwości po hospitalizacji - w pierwszych 30 dniach, natomiast jednoczesne stosowanie beta-adrenolityku i iwabradyny u chorych ustabilizowanych po dekompensacji powoduje istotne zwolnienie częstości HR i poprawę LVEF, zarówno w krótko-, jak i w długotrwałej obserwacji [38].

\section{Podsumowanie}

Profil pacjenta z HF w ostatnich latach istotnie się zmienił. Współcześni pacjenci mają nie tylko inną charakterystykę kliniczną, ale także inne potrzeby niż chorzy leczeni jeszcze kilka lat temu. Obecnie potrzebne są leki, które zarówno obniżają ryzyko zgonu pacjentów z HF, jak i korzystnie wpływają na ryzyko powtórnych hospitalizacji, normalizują parametry hemodynamiczne i poprawiaja 
tolerancję wysiłku. Takim lekiem okazała się iwabradyna, która istotnie zmniejsza częstość HR, a także korzystnie wpływa na wszystkie wymienione parametry. Jednocześnie stanowi ona najnowocześniejszą formę leczenia dla pacjentów z HF. Dalsza optymalizacja farmakoterapii zwłaszcza z zastosowaniem leków o dobrze udowodnionym korzystnym wpływie na rokowanie pacjentów - może się przyczynić do poprawy długoletniego przeżycia w tej grupie.

\section{Konflikt interesów}

Grupa Ekspertów dąży do zapewnienia niezależności i obiektywizmu we wszystkich swoich działaniach edukacyjnych. Celem działań Grupy Ekspertów, które doprowadziły do powstania niniejszego opracowania, nie jest promowanie, popieranie lub zalecanie w szczególny sposób produktu handlowego, którego opis znalazł się w artykule. Autorzy nie zgłaszają konfliktu interesów.

\section{Abstract}

Accelerated heart rate is a risk factor of general and cardiovascular mortality in different populations. The classical treatment to achieve heart rate reduction by beta-blockers and calcium channel antagonists from the group of non-dihydropyridines (verapamil and diltiazem), is often limited by contraindications or adverse reactions. Ivabradine is a unique, modern drug which mechanism of action is blocking the $\mathrm{I}_{\mathrm{f}}$ current in the sinoatrial node. This translates into a reduction in heart rate - a parameter associated with poor prognosis in patients with heart failure. The following document contains the opinion of an expert group summarizing current knowledge on ivabradine and its use in population of patients with heart failure.

Key words: therapy optimization, heart failure, ivabradine

Folia Cardiologica 2018; 13, 6: 534-544

\section{Piśmiennictwo}

1. Czech M, Opolski G, Zdrojewski T, et al. The costs of heart failure in Poland from the public payer's perspective. Polish programme assessing diagnostic procedures, treatment and costs in patients with heart failure in randomly selected outpatient clinics and hospitals at different levels of care: POLKARD. Kardiol Pol. 2013; 71(3): 224-232, doi: 10.5603/KP.2013.0032, indexed in Pubmed: 23575775.

2. Heidenreich PA, Albert NM, Allen LA, et al. American Heart Association Advocacy Coordinating Committee, Council on Arteriosclerosis, Thrombosis and Vascular Biology, Council on Cardiovascular Radiology and Intervention, Council on Clinical Cardiology, Council on Epidemiology and Prevention, Stroke Council. Forecasting the impact of heart failure in the United States: a policy statement from the American Heart Association. Circ Heart Fail. 2013; 6(3): 606-619, doi: 10.1161/ /HHF.0b013e318291329a, indexed in Pubmed: 23616602.

3. McMurray JJV, Adamopoulos S, Anker SD, et al. ESC Committee for Practice Guidelines. ESC Guidelines for the diagnosis and treatment of acute and chronic heart failure 2012: The Task Force for the Diagnosis and Treatment of Acute and Chronic Heart Failure 2012 of the European Society of Cardiology. Developed in collaboration with the Heart Failure Association (HFA) of the ESC. Eur Heart J. 2012; 33(14): 1787-1847, doi: 10.1093/eurheartj/ehs104, indexed in Pubmed: 22611136.

4. Wożakowska-Kapłon B, Mamcarz A, Filipiak KJ. Iwabradyna w terapii niewydolności serca - od teorii do praktyki. Medical Education, Warszawa 2014.

5. Bleumink GS, Knetsch AM, Sturkenboom MC, et al. Quantifying the heart failure epidemic: prevalence, incidence rate, lifetime risk and prognosis of heart failure The Rotterdam Study. Eur Heart J. 2004;
25(18): 1614-1619, doi: 10.1016/j.ehj.2004.06.038, indexed in Pubmed: 15351160.

6. Rywik TM, Koziarek J, Piotrowski W, et al. Trends in heart failure mortality in Poland between 1980 and 2010. Pol Arch Med Wewn. 2013; 123(12): 664-671, indexed in Pubmed: 24162363.

7. Gierczyński J, Gryglewicz J, Karczewicz E, Zalewska H. Niewydolność serca - analiza kosztów ekonomicznych i społecznych. Instytut Zarządzania w ochronie zdrowia 2013. http://niewydolnosc-serca pl/ /ns_raport2013.pdf (4.12.2018).

8. http://apps who int/medicinedocs/documents/s22177en/ /s22177en.pdf. OECD 2015 Avoidable hospital admissions in Health at a Glance 2015: OECD Indicators, OECD Publishing, Paris. (06.12.2018).

9. Maron BJ, Towbin J, Thiene G, et al. Contemporary definitions and classification of the cardiomyopathies. Circulation. 2006; 113(14): 1807-1816, doi: 10.1161/circulationaha.106.174287.

10. McAlister FA, Wiebe N, Ezekowitz JA, et al. Meta-analysis: beta-blocker dose, heart rate reduction, and death in patients with heart failure. Ann Intern Med. 2009; 150(11): 784-794, indexed in Pubmed: 19487713.

11. Rywik TM, Kołodziej P, Targoński R, et al. Characteristics of the heart failure population in Poland: ZOPAN, a multicentre national programme. Kardiol Pol. 2011; 69(1): 24-31, indexed in Pubmed: 21267960.

12. Jankowska $E$, Ponikowski $P$. Prevalence of high resting heart rate in the contemporary population of patients with systolic heart failure in real life: the results from DATA-HELP. Heart Failure, Belgrad, 2012.

13. Kasprzak JD, Stępińska J, Wożakowska-Kapłon B, et al. Optymalna częstość rytmu serca - aktualny cel terapii kardiologicznej. Stanowisko 
grupy ekspertów Sekcji Farmakoterapii Sercowo-Naczyniowej Polskiego Towarzystwa Kardiologicznego. Kardiol Pol. 2012; 70(10): 1081$-1094$.

14. Solomon SD, Dobson J, Pocock S, et al. Candesartan in Heart failure: Assessment of Reduction in Mortality and morbidity (CHARM) Investigators. Influence of nonfatal hospitalization for heart failure on subsequent mortality in patients with chronic heart failure. Circulation. 2007; 116(13): 1482-1487, doi: 10.1161/CIRCULATIONAHA. 107.696906, indexed in Pubmed: 17724259.

15. DeVore AD, Mi X, Mentz RJ, et al. Discharge heart rate and $\beta$-blocker dose in patients hospitalized with heart failure: Findings from the $\mathrm{OP}$ TIMIZE-HF registry. Am Heart J. 2016; 173: 172-178, doi: 10.1016/j. ahj.2015.10.026, indexed in Pubmed: 26920611.

16. Fonarow GC, Abraham WT, Albert NM, et al. Dosing of beta-blocker therapy before, during, and after hospitalization for heart failure (from Organized Program to Initiate Lifesaving Treatment in Hospitalized Patients with Heart Failure). Am J Cardiol. 2008; 102(11): 1524-1529, doi: 10.1016/j.amjcard.2008.07.045, indexed in Pubmed: 19026308.

17. Opolski G, Ozierański K, Lelonek M, et al. Adherence to the guidelines on the management of systolic heart failure in ambulatory care in Poland. Data from the international QUALIFY survey. Pol Arch Intern Med. 2017; 127(10): 657-665, doi: 10.20452/pamw.4083, indexed in Pubmed: 28786405.

18. Difrancesco D, Camm JA. Heart rate lowering by specific and selective I(f) current inhibition with ivabradine: a new therapeutic perspective in cardiovascular disease. Drugs. 2004; 64(16): 1757-1765, doi: 10.2165/00003495-200464160-00003, indexed in Pubmed: 15301560.

19. Accili EA, Proenza C, Baruscotti M, et al. From funny current to $\mathrm{HCN}$ channels: 20 years of excitation. News Physiol Sci. 2002; 17: 32-37, indexed in Pubmed: 11821534.

20. DiFrancesco D, Tortora P. Direct activation of cardiac pacemaker channels by intracellular cyclic AMP. Nature. 1991; 351(6322): 145-147, doi: 10.1038/351145a0, indexed in Pubmed: 1709448.

21. Difrancesco D. Pacemaker mechanisms in cardiac tissue. Ann Rev Physiol. 1993; 55: 455-472, doi: 10.1146/annurev. ph.55.030193.002323, indexed in Pubmed: 7682045.

22. Bucchi A, Baruscotti M, DiFrancesco D. Current-dependent block of rabbit sino-atrial node I(f) channels by ivabradine. J Gen Physiol. 2002; 120(1): 1-13, indexed in Pubmed: 12084770.

23. Charakterystyka produktu leczniczego Ivohart $5 \mathrm{mg} ; 7,5 \mathrm{mg}$, tabletki powlekanie 12.05.2018.

24. Thollon C, Bidouard JP, Cambarrat C, et al. Stereospecific in vitro and in vivo effects of the new sinus node inhibitor (+)-S 16257. Eur J Pharmacol. 1997; 339(1): 43-51, indexed in Pubmed: 9450615.

25. Simon L, Ghaleh B, Puybasset L, et al. Coronary and hemodynamic effects of $S 16257$, a new bradycardic agent, in resting and exercising conscious dogs. J Pharmacol Exp Ther. 1995; 275(2): 659-666, indexed in Pubmed: 7473152.

26. Colin P, Ghaleh B, Hittinger L, et al. Differential effects of heart rate reduction and beta-blockade on left ventricular relaxation during exercise. Am J Physiol Heart Circ Physiol. 2002; 282(2): H672-H679, doi: 10.1152/ajpheart.00547.2001, indexed in Pubmed: 11788417.
27. Berdeaux A. Preclinical results with I(f) current inhibition by ivabradine. Drugs. 2007; 67(Suppl 2): 25-33, doi: 10.2165/00003495200767002-00004, indexed in Pubmed: 17999561.

28. De Ferrari GM, Mazzuero A, Agnesina L, et al. Favourable effects of heart rate reduction with intravenous administration of ivabradine in patients with advanced heart failure. Eur J Heart Fail. 2008; 10(6): 550-555, doi: 10.1016/j.ejheart.2008.04.005, indexed in Pubmed: 18486549.

29. Borer JS, Fox K, Jaillon P, et al. Ivabradine Investigators Group. Antianginal and antiischemic effects of ivabradine, an I(f) inhibitor, in stable angina: a randomized, double-blind, multicentered, placebo-controlled trial. Circulation. 2003; 107(6): 817-823, indexed in Pubmed: 12591750.

30. Swedberg K, Komajda M, Böhm M, et al. SHIFT Investigators. Ivabradine and outcomes in chronic heart failure (SHIFT): a randomised placebo-controlled study. Lancet. 2010; 376(9744): 875-885, doi: 10.1016/ /S0140-6736(10)61198-1, indexed in Pubmed: 20801500.

31. Swedberg K, Komajda M, Böhm M, et al. SHIFT Investigators. Rationale and design of a randomized, double-blind, placebo-controlled outcome trial of ivabradine in chronic heart failure: the Systolic Heart Failure Treatment with the I(f) Inhibitor Ivabradine Trial (SHIFT). Eur J Heart Fail. 2010; 12(1): 75-81, doi: 10.1093/eurjhf/hfp154, indexed in Pubmed: 19892778.

32. Ponikowski P, Voors A, Anker S, et al. Wytyczne ESC dotyczące diagnostyki i leczenia ostrej i przewlekłej niewydolności serca w 2016 roku. Kardiol Pol. 2016; 74(10): 1037-1147, doi: 10.5603/kp.2016.0141.

33. Ferrari R, Ford I, Fox K, et al. Beautiful Study Group. The BEAUTIFUL study: randomized trial of ivabradine in patients with stable coronary artery disease and left ventricular systolic dysfunction - baseline characteristics of the study population. Cardiology. 2008; 110(4): 271-282, doi: 10.1159/000112412, indexed in Pubmed: 18595216.

34. Fox K, Ford I, Steg PG, et al. BEAUTIFUL investigators. Heart rate as a prognostic risk factor in patients with coronary artery disease and left-ventricular systolic dysfunction (BEAUTIFUL): a subgroup analysis of a randomised controlled trial. Lancet. 2008; 372(9641): 817-821, doi: 10.1016/S0140-6736(08)61171-X, indexed in Pubmed: 18757091.

35. Tardif JC, Ponikowski P, Kahan T, et al. ASSOCIATE Investigators. Effects of ivabradine in patients with stable angina receiving $\beta$-blockers according to baseline heart rate: an analysis of the ASSOCIATE study. Int J Cardiol. 2013; 168(2): 789-794, doi: 10.1016/j.jicard.2012.10.011, indexed in Pubmed: 23138014.

36. Tardif JC, O'Meara E, Komajda M, et al. SHIFT Investigators. Effects of selective heart rate reduction with ivabradine on left ventricular remodelling and function: results from the SHIFT echocardiography substudy. Eur Heart J. 2011; 32(20): 2507-2515, doi: 10.1093/ /eurheartj/ehr311, indexed in Pubmed: 21875858.

37. Fox K, Ford I, Steg P, et al. Ivabradine in stable coronary artery disease without clinical heart failure. N Engl J Med. 2014; 371(12): 1091-1099, doi: 10.1056/nejmoa1406430, indexed in Pubmed: 25176136.

38. Hidalgo FJ. Early therapy with beta blockers plus ivabradine versus beta blockers alone in patients hospitalised with heart failure and reduced ejection fraction (ETHIC-AHF Study): results at one-year follow-Up. Int J Clin Cardiol. 2017; 4(1), doi: 10.23937/2378 2951/1410093. 